\title{
NOTE
}

\section{Picorna-like virus associated with mortality and a spongious encephalopathy in grouper Epinephelus malabaricus}

\author{
S. Boonyaratpalin ${ }^{1}$, K. Supamattaya ${ }^{2, *}$, J. Kasornchandra ${ }^{1}$, R. W. Hoffmann ${ }^{3}$ \\ ${ }^{1}$ National Institute of Coastal Aquaculture, Songkla 90000, Thailand \\ ${ }^{2}$ Department of Aquatic Science, Faculty of Natural Resources, Prince of Songkla University, Had Yai, Songkla 901 10, Thailand \\ ${ }^{3}$ Institute of Zoology, Fisheries Biology and Fish Disease, Kaulbachstr. 37, D-80539 Munich, Germany
}

\begin{abstract}
A picorna-like virus was detected from diseased fry and fingerling grouper Eipinephelus malabaricus cultured in southern Thailand. Affected grouper exhibited dark coloration of the head and tail, loss of equilibrium and corkscrew-like swimming. Pathological changes of affected fish showed vacuolating encephalopathy and retinopathy. Intracytoplasmic inclusions were observed in the nerve cells. From electron microscopic studies, virus particles could be detected in the brain and eyeball of affected fishes. They were round to icosahedral, without an envelope, 20 to $25 \mathrm{~nm}$ in diameter and had an electron dense core of $16 \mathrm{~nm}$. Filtrates $(0.45 \mu \mathrm{m}\}$ of affected brain and eyeball tissues can produce the same clinical signs in healthy grouper after injection, and the identical virus particles could be observed in the brain and retuna of experimentally infected fish.
\end{abstract}

KEY WORDS: Picorna-like virus - Grouper - Epinephelus malabaricus $\cdot$ Spongious encephalopathy

Since 1983, the grouper Epinephelus malabaricus has been an important species for cage culture as it commands a higher market price than other major commercially farmed marine fish in southeast Asia, such as sea bass Lates calcarifer and red snapper Lutianus argentimaculatus. The cage culture of grouper has expanded rapidly in southern Thailand, Malaysia, Singapore and Taiwan, relying almost entirely on grouper fingerlings collected from the wild for cage stocking. Grouper spawning, larvae and fry-rearing techniques are still only in the experimental stages. Lack of knowledge concerning these techniques, coupled with a general lack of knowledge concerning diseases of marine fish species, are the main obstacles inhibiting the successful development of grouper culture in the region.

For many years, the mass mortalities characterized by darting to corkscrew-like swimming, anorexia and

- Addressee for correspondence blackish coloration have been observed among fry and fingerling of grouper Epinephelus malabaricus reared in hatcheries in southern Thailand. Similar clinical signs have been reported among marine fishes such as the baramundi Lates calcarifer (Glazebrook et al. 1990), the Japanese parrotfish Oplegnathus fasciatus (Yoshikoshi \& Inoue 1990), seabass Dicentrarchus labrax (Breuil et al. 1991), turbot Scophthalmus maximus (Bloch et al. 1991) the redspotted grouper Epinephelus akaara (Mori et al. 1991) and the striped jack Pseudocaranx dentex (Mori et al. 1992). Electron microscopic observation revealed a picorna-like virus associated with those affected fish. The virus observed in the brain and retina of diseased striped jack was identified as a member of the Nodaviridae based on its nucleic acid properties.

This paper dercribes histopathological changes in grouper larvae and fingerlings, both from cultured and wild fish, and the possibility of a causative viral agent is discussed.

Materials and methods. Fish. Grouper Epinephelus malabaricus fry and fingerlings ranging from 2 to $5 \mathrm{~cm}$ in length were collected along the east coast of the south China Sea, Thailand. Fish were kept in aerated hatchery tanks equipped with flowing seawater. They were fed with Artemia sp. nauplii and subsequently with fresh minced fish. During rearing, the fish developed corkscrew-like swimming, anorexia and blackish coloration of the body prior to death. Moribund fish were collected for further examination.

Parasitological and microbiological examinations. Twenty fish were examined for parasitological infestation of the gills, skin, eyes and internal organs. Bacteriological examinations were performed using methods described by Shotts \& Teska (1989).

Histological examination. Tissues of gills, skin, brain, eyes and other internal organs from 20 fish were fixed in Bouin's fixative for $48 \mathrm{~h}$ and processed for stan- 
dard histological preparations. Paraffin sections, 4 to $5 \mu \mathrm{m}$ in thickness, were stained with hematoxylin and eosin and observed by light microscopy.

Electron microscopy. The brain, eyeball and internal organs of the same diseased fish mentioned above were fixed in $6.25 \%$ Sorensen buffered glutaraldehyde (pH 7.4) for 2 to $3 \mathrm{~h}$ and post-fixed in $1 \% \mathrm{OsO}_{4}$ for $1 \mathrm{~h}$. Tissues were then embedded in synthetic resin (Epon-812). Semithin sections, $0.5 \mu \mathrm{m}$ in thickness, were stained with toluidine blue and examined by light microscopy. Ultrathin sections, 50 to $100 \mathrm{~nm}$, were contrasted with uranyl acetate and lead citrate and viewed by electron microscopy (EM; Jeol $100 \mathrm{cx}$ ) at $80 \mathrm{kV}$ accelerating voltage.

Infectivity trials. To determine the pathogenic nature of the causative agent, brain and eyeball tissues of diseased fish were harvested and homogenized in cell culture medium (L-15) at the ratio $1: 10$. They were centrifuged at $3000 \times g$ for $10 \mathrm{~min}$ at $4^{\circ} \mathrm{C}$. The supernatant fluid was filtered through $0.45 \mu \mathrm{m}$ membrane which had been coated with $1 \%$ fetal calf serum and the filtrate used immediately after filtration. Two groups of 10 grouper each $(2.0$ to $3.0 \mathrm{~g})$ were injected intraperitoneally with $0.1 \mathrm{ml}$ of the filtrates of brain and eyeball. A group injected with L-15 medium served as the control. Filtrates of affected brain and eyeball of previously experimentally infected fish were passaged through the healthy grouper up to 5 times. Fish were held in $20 \mathrm{l}$ aquaria and fed with fresh minced fish 3 times daily. The fish were observed for $10 \mathrm{~d}$, and all moribund fish were preserved for histological and EM study as previously described.

Results. During the rearing period, grouper fingerlings showed signs of disease such as darkening of the head and tail, loss of equilibrium and corkscrew-like swimming. The mortality ranged from 40 to $60 \%$ under the rearing conditions of the hatchery and higher in cage cultures along the shore (50 to $80 \%$ ). Parasitological examination of gills and skin revealed a small number of external parasites (Trichodinids, Cryptocaryon, and Diplectanum sp.). No relationship between the clinical signs and parasitic infestation could be shown. No pathogenic bacteria were isolated from affected fish.

Histopathological changes were observed mainly in the brain and eyeball but also in some other organs examined. Affected brain showed pathological changes primarily in the olfactory lobe (telencephalon) and cerebellum. These included severe spongious encephalopathy, necrosis and degeneration of nerve cells in the brain (Fig. 1). Affected nerve cells usually contained roundish basophilic intracytoplasmic inclusion bodies. Only mild tissue reaction could be observed by mononuclear cells in surrounding area. In severe cases, mild vacuolation in the medulla oblongata and spinal cord were visible. Pathological changes in the eyeball consisted of a vacuolating retinopathy. In severe cases, sloughing of affected cells from the retina were observed floating in the eye chamber (corpus vitrium) (Fig. 2). Other affected organs, such as the liver, exhibited mild vacuolation and in some cases large numbers of eosinophilic substances accumulated in the cytoplasm of liver cells. Affected fish showed numerous vacuoles in the mucosal layer of the intestine (Fig. 3), and the hemopoeitic tissue of the kidney, as well as the spleen, also exhibited mild vacuolation compared to similar tissues in healthy fish.

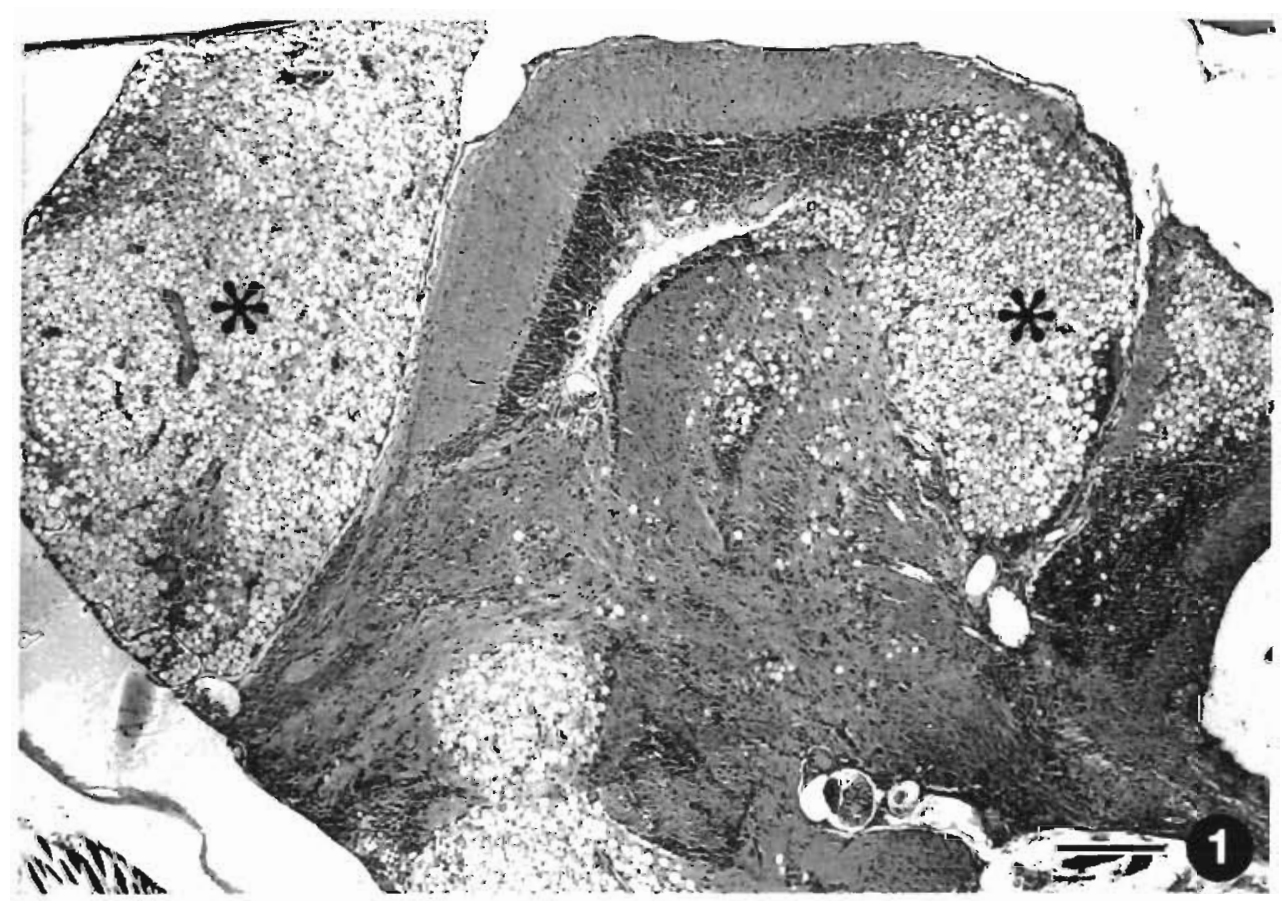

Fig. 1. Epinephelus malabaricus. Light micrograph of the brain of infected grouper fingerling showing severe vacuolation $(*)$. H\&E. Scale bar $=200 \mu \mathrm{m}$ 
Fig. 2. Epinephelus malabaricus. High magnification of retina from infected grouper exhibiting vacuolation of cell layer. $\mathrm{H} \& \mathrm{E}$. Scale bar $=50 \mu \mathrm{m}$

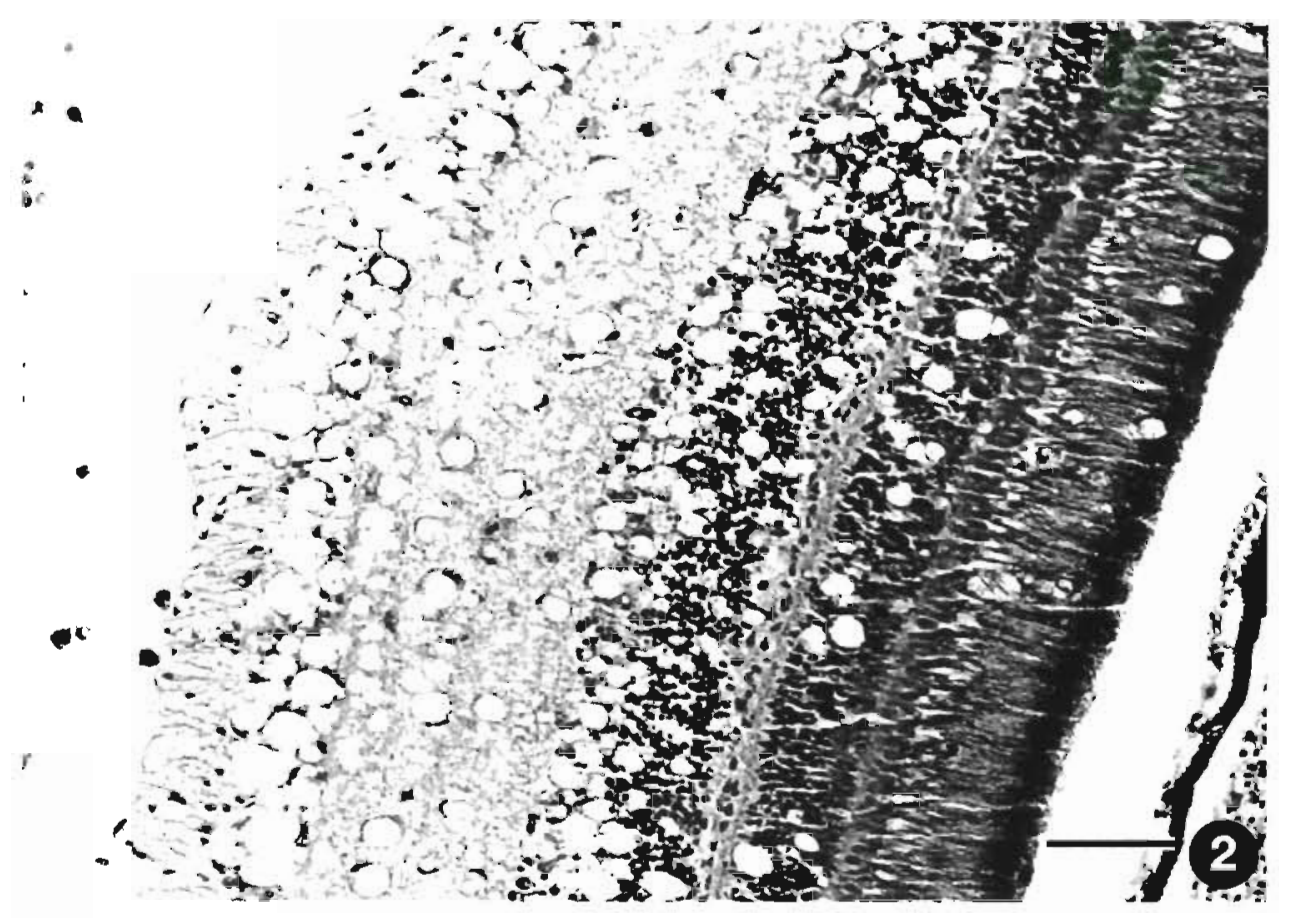

Fig. 3. Epinephelus malabaricus. Vacuolation in the intestine of infected grouper. H\&E. Scale bar $=50 \mu \mathrm{m}$

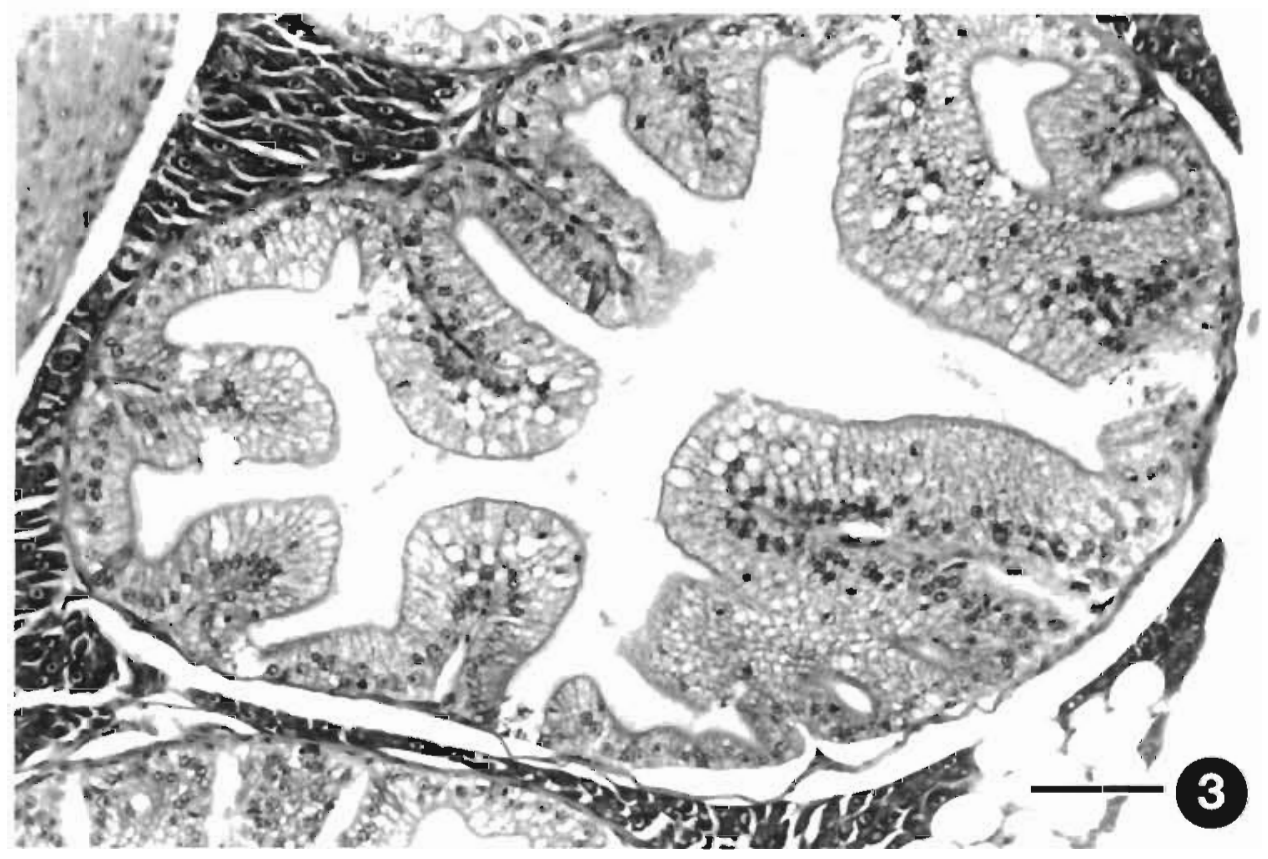

Experimental infection trials showed that the filtrate from diseased grouper can produce mortality in healthy grouper 4 to $5 \mathrm{~d}$ postinfection. The mortality can occur as long as $10 \mathrm{~d}$ postinfection (Table 1), and infectivity can be passaged to healthy grouper up to 5 times by using the brain tissues of previously infected grouper. Infected fish show clinical signs similar to those observed in natural infections, and histological examination of affected fish tissues revealed the same pathological changes as observed in natural infec- tions. EMs of the brain and retina of both experimentally and naturally infected grouper exhibited numerous virus particles and cytoplasmic inclusions in the nerve cells (Figs. $4 \& 5$ ). The intracytoplasmic inclusion presented in the nerve cells of the moribund fish contained numerous virus particles 20 to $25 \mathrm{~nm}$ in diameter with an electron dense core of $16 \mathrm{~nm}$. The virus was morphologically round to icosahedral and had no envelope. The characteristic paracrystalline arrays and virus aggregation, either membrane- 


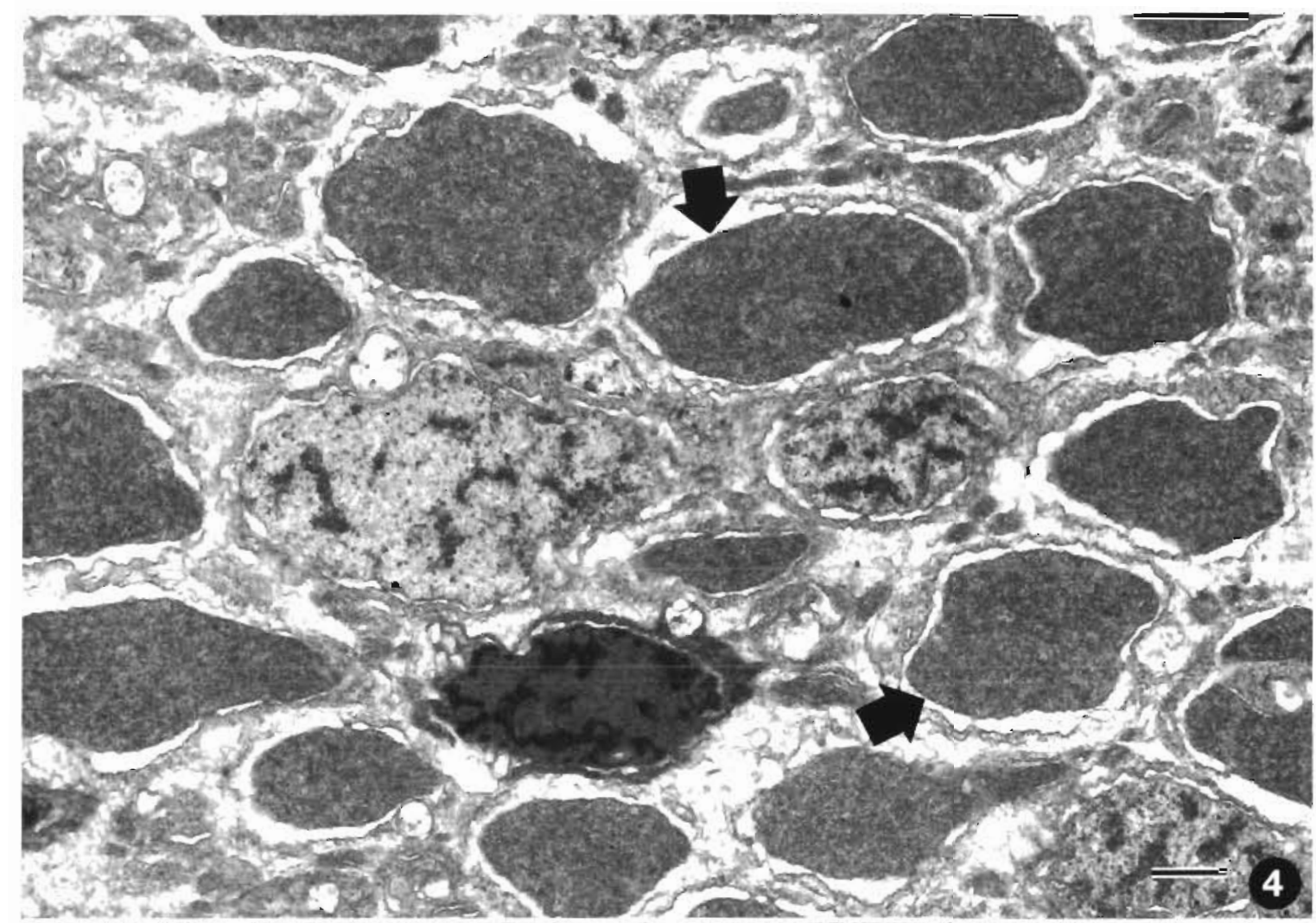

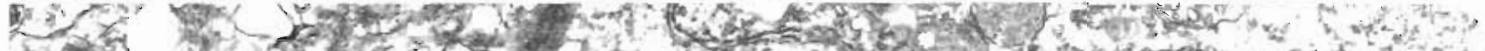

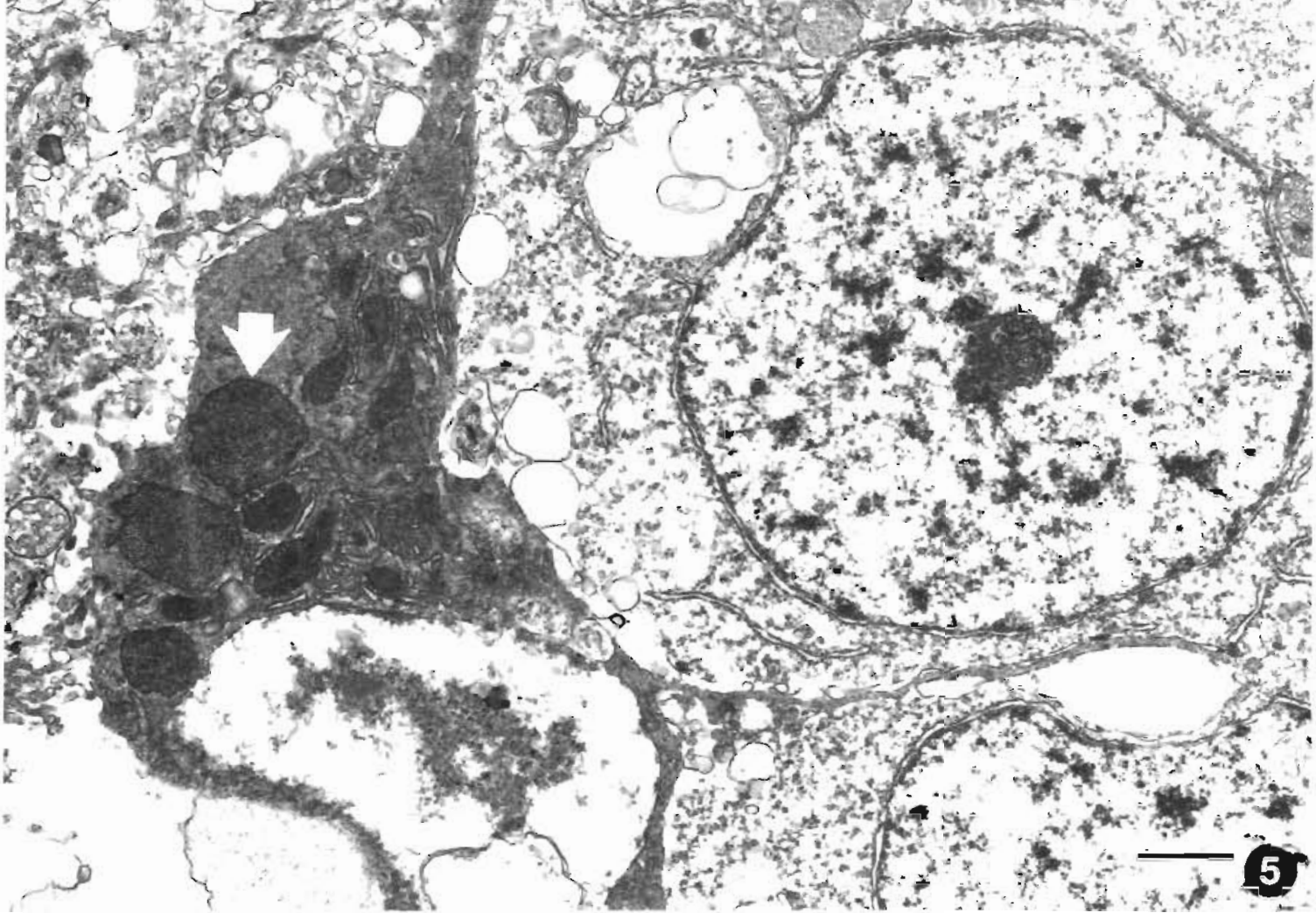

Figs 4 \& 5 Epinephelus malabancus. Fig 4 Electron micrograph of affected retina indicated presence of intracytoplasmic inclusions of virus (arrows) Uranyl acetate \& lead citrate. Scale bar $=1 \mu \mathrm{m}$ Flg 5 Electron micrograph of affected brain exhibiting nerve cell degeneration with intracytoplasmic inclusions of virus (arrow) Uranyl acetate \& lead citrate. Scale bar $=1 \mu \mathrm{m}$ 
Table 1 Epinephelus malabaricus. Survival of grouper fingerlings (given as no. of fish surviving/no. inoculated) after injection with cell-free filtrates of affected brain and eyeball tissues from diseased grouper. HBSS: Hank's balanced salt solution

\begin{tabular}{|c|c|c|c|c|c|c|c|c|c|c|}
\hline \multirow{2}{*}{ Inoculum } & \multicolumn{10}{|c|}{ Days postinjection } \\
\hline & 1 & 2 & 3 & 4 & 5 & 6 & 7 & 8 & 9 & 10 \\
\hline HBSS control & $10 / 10$ & $10 / 10$ & $10 / 10$ & $10 / 10$ & $10 / 10$ & $10 / 10$ & $10 / 10$ & $10 / 10$ & $10 / 10$ & $10 / 10$ \\
\hline Filtrate of eyeball & $10 / 10$ & $10 / 10$ & $10 / 10$ & $9 / 10$ & $9 / 10$ & $8 / 10$ & $8 / 10$ & $6 / 10$ & $5 / 10$ & $5 / 10$ \\
\hline Filtrate of brain & $10 / 10$ & $10 / 10$ & $10 / 10$ & $10 / 10$ & $8 / 10$ & $8 / 10$ & $6 / 10$ & $5 / 10$ & $4 / 10$ & $4 / 10$ \\
\hline
\end{tabular}

bound on the endoplasmic reticulum or free in the cytoplasm, were observed among free virus particles in the cytoplasm of the infected cells (Fig. 6). The virus seemed to be replicate only in the cytoplasm, where aggregation was associated with the cytoplasmic membrane.

Discussion. This paper describes a viral agent associated with mortalities of the grouper Epinephelus malabaricus cultured in Thailand. Many parasitic infestation and bacterial infection have been reported in fingerling and adult grouper cultured in cages (Supamattaya et al. 1990, 1991), but none of those organisms were proven to be the causative agents of mass mortality in grouper fingerlings associated with the signs of black tail, loss of equilibrium and corkscrew-swimming. Nutritional disorder is another suspected cause, but many nutritional ingredients have been tested on grouper and the signs of deficiency of each diet have not corresponded to the clinical signs observed.

Experimental infection, using cell-free filtrates of brain and eyeball tissue from diseased grouper, produced the same clinical signs and mortality as observed in natural infections. This reinfection trial can be successfully transmitted up to 5 times by using cell-

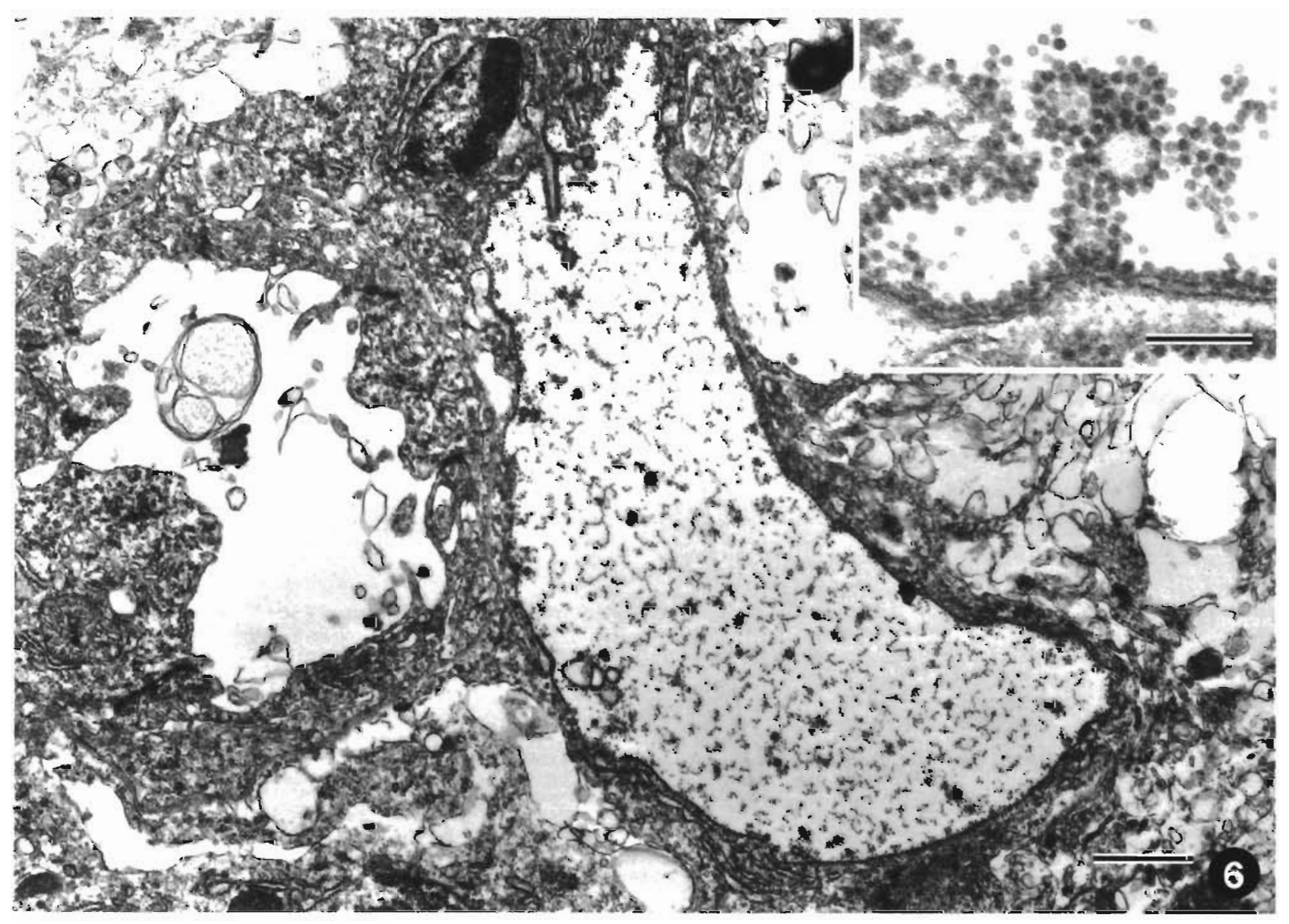

Fig. 6. Epinephelus malabaricus. Electron micrograph of affected brain showing free virus particle in the vacuole of unidentified nerve cell. Scale bar $=1 \mu \mathrm{m}$. Inset shows higher magnification of virus particle. Uranyl acetate \& lead citrate. Scale bar $=0.2 \mu \mathrm{m}$ 
free filtrates of the brain from the previous reinfected grouper. EMs of the brain and retina of naturally infected and experimentally infected grouper revealed identical virus particles. This indicates that the virus induced mortality in grouper in the laboratory. However, we cannot exclude the possibility that other factors (water parameters, nutritional disorder, and toxic chemicals) are involved in producing mortality in grouper fingerlings in the wild or in cage cultures.

Pathological changes observed in affected grouper showed similarities to those previously reported in picorna-like virus infections in many marine fishes. Glazebrook et al. (1990), Renault et al. (1991) and Munday et al. (1992) reported a picorna-like virus in the brain and retina of the barramundi Lates calcarifer. Pathological changes of those affected fish were similar to those found in the present study, i.e. vacuolating encephalopathy and retinopathy as well as necrosis and karyorrhexis of neural cells. EMs of affected brain and retina showed non-enveloped virus particles 25 to $30 \mathrm{~nm}$ in diameter with an icosahedral structure in the cytoplasm. Failure to reproduce the virus both in vivo and in vitro was reported with a picorna-like virus in the hatchery-reared seabass Dicentrarchus labrax; however, pathological changes of the brain and retina of affected fish showed similarity to the other picornalike virus infections (Breuil et al. 1991). In our studies, virus from grouper can be passed on through animals (grouper fingerlings) and induce clear clinical and pathological signs. Two picorna-like viruses have been isolated, so far, one from the European smelt Osmerus eperlanus and the other one from steelhead trout Oncorhynchus mykiss (Ahne et al. 1990, Eaton et al. 1992). It seems that this group of viruses affects primarily young marine fishes and none have been reported from fresh water fish.

Natural infection of grouper with this virus was not acute as indicated by the mortality in the laboratory and from natural infections. However, the disease outbreak can be severe when the occurrence of viruses is coupled with stress conditions in the culture system. This could cause mortality during the rearing period of grouper fingerlings. Good husbandry and sanitation in the hatchery could reduce the virulence of virus. The present results show that an infectious encephalopathy is occurring in grouper. The evidence of EM studies revealed virions which are morphologically like picorna-virus. This is also supported by structural comparison with others picorna-like virus infections in marine fish (Bloch et al. 1991, Breuil et al. 1991, Renault et al. 1991, Munday et al. 1992). Future studies will involve characterization of this virus in detail and

Responsible Subject Editor: F. M. Hetrick, College Park, Maryland, USA a determination of the effects of chemical and physical agents on this virus and its transmission from brood fish to egg (vertical transmission).

Acknowledgements. This work was supported by Prince of Songkla University Foundation Funds. Thanks go to Dr A. E. Cronin, Prof. Dr E. Dahme and Prof. Dr Muroga for their valuable comments. Thanks to The Electron Microscopy Unit, Prince of Songkla University, and Rubber Research Center for the EM facilities.

\section{LITERATURE CITED}

Ahne W, Anders K, Halder M, Yoshimizu M (1990) Isolation of picorna virus-like particles from the European smelt, Osmerus eperlanus (L.). J Fish Dis 13:167-168

Bloch B, Gravningen K, Larsen JL (1991) Encephalomyelitis among turbot associated with a picorna-like agent. Dis Aquat Org 10:65-70

Breuil G, Bonami JR, Pepin JF, Pichot Y (1991) Viral infection (picorna-like virus) associated with mass mortalities in hatchery-reared sea bass (Dicentrarchus labrax) larvae and juveniles. Aquaculture 97:109-116

Eaton WD, Bagshaw J, Hulett J, Evans S (1992) Isolation of a picorna-like virus from Steelhead in Washington State. $\mathrm{J}$ Aquat Anim Health 4:90-96

Glazebrook JS, Heasman MP, Beer SW (1990) Picorna-like viral particles associated with mass mortalities in larval barramundi, Lates calcarifer Bloch. J Fish Dis 13:245-249

Mori K, Nakai T, Muroga K. Arimoto M, Mushiake K, Furusawa I (1992) Properties of a new virus belonging to Nodaviridae found in larval striped jack (Pseudocaranx dentex) with nervous necrosis. Virology 187:368-371

Mori K, Nakai T, Nagahara M, Muroga K, Mekuchi T, Kanno $T$ (1991) A viral disease in hatchery-reared larvae and juveniles of redspotted grouper Gyobyo Kenkyu 26 $209-210$

Munday BL, Langdon JS, Hyatt A, Humphrey JD (1992) Mass mortality associated with a viral-induced vacuolating encephalopathy and retinopathy of larval and juvenile barramundi, Lates calcarifer Bloch. Aquaculture 103: $197-211$

Renault T, Haffner P, Baudin Laurenein F, Brevil G, Bonami JR (1991) Mass mortality in hatchery-reared seabass (Lates calcarifer) larvae associated with the presence in the brain and retina of virus-bke particles. Bull Eur Ass Fish Pathol 11:68-73

Shotts EB, Teska, JD (1989) Bacterial pathogens of aquatic vertebrates. In: Austin B, Austin DA (eds) Methods for the microbiological examination of fish and shellfish. Ellis Horwood Ltd, Chichester, p 164-182

Supamattaya K, Fischer-Scherl T, Hoffmann RW, Boonyaratpalin $S$ (1990) Renal sphaerosporosis in cultured grouper Epinephelus malabaricus. Dis Aquat Org 8:35-38

Supamattaya K, Fischer-Scherl T, Hoffmann RW, Boonyaratpalin S (1991) Sphaerospora epinepheli n. sp. (Myxosporea: Sphaerosporidae) observed in grouper (Epinephelus malabaricus). J Protozool 38:448-454

Yoshikoshi K, Inoue K (1990) Viral nervous necrosis in hatchery-reared larvae and juveniles of Japanese parrotfish, Oplegnathus fasciatus (Temminck \& Schlegel). J Fish Dis 13:69-77

Manuscript first received: June 16, 1995

Revised version accepted: January 22, 1996 